\title{
MYTH, NEO-COLONIALISM AND NEO-NOIR IN TWO FILMS BY DAIN SAID
}

\author{
(Mitos, Neo-Kolonialisme dan Neo-Noir dalam Dua Filem \\ Arahan Dain Said)
}

\author{
A. Wahab Hamzah \\ wahab@dbp.gov.my
}

Dewan Bahasa dan Pustaka Wilayah Utara.

Published online: 3 December 2018

To cite: A. Wahab Hamzah. (2018). Myth, neo-colonialism and neonoir in two films by Dain Said. Malay Literature 31(2), 383 - 392.

\begin{abstract}
Dain Said is one of the most reputable Malaysian film directors. Two of his films, Bunohan (2011) and Interchange (2016), not only won him awards for best film and best director but were also screened in many respected world film festivals. Bunohan and Interchange have a reputation of being different from many ordinary contemporary Malay films. Both films contain the similar theme of killing in their plots with a dark noirist approach, but killing is only on the surface of their multi-layered narratives. In both films, Dain is interested in the interweaving myth, imperialism and capitalism in the conflict of tradition and modernization. Even though myth has been imbued with fantastic elements, it becomes part of the ideological process of naturalization and has its own role in the origin of the race, history, and identity of a country. Colonialization and capitalism have been gradually destroying traditional cultures and myths that are part of a nation's ideology. This essay analyzes how traditional cultures and mythologies should become the important elements in resisting the dangers of neo-colonialism that is called globalization. Here, the films Bunohan and Interchange have proved that Dain Said is a film auteur in his own class.
\end{abstract}

Keywords: myth, colonialism, auteur, Malay film, neo-noir 


\begin{abstract}
Dain Said salah seorangpengarahfilem Malaysiayang berkemampuan tinggi. Dua filem arahannya, Bunohan (2011) dan Interchange (2016) bukan sahaja memenangi anugerah filem terbaik dan pengarah terbaik malah banyak ditayangkan di festival filem dunia yang berprestij. Bunohan dan Interchange berbeza dengan kebanyakan filem Melayu kontemporari. Kedua-dua filem memaparkan tema dan plot yang sama, iaitu pembunuhan dengan pendekatan noirist. Walau bagaimanapun pembunuhan hanya lapisan permukaan yang terdiri daripada beberapa lapis naratif. Dalam kedua-dua flem Dain berminat dengan menggabungkan mitos, imperialisme dan kapitalisme dalam konflik tradisi dan modern. Walaupun mitos bercampur dengan elemen fantasi, tetapi mitos menjadi sebahagian proses ideologi peneutralan. Mitos mempunyai peranannya dalam asal usul bangsa, sejarah dan identiti negara. Kolonialisasi dan kapitalisme dalam diam membunuh budaya tradisi dan mitos yang menjadi sebahagian daripada ideologi negara. Makalah ini menganalisis budaya tradisi dan mitos yang sepatutnya menjadi elemen penting dalam menolak perangkap neo-kolonialisme atau lebih dikenali sebagai globalisasi. Filem Bunohan dan Interchange membuktikan Dain Said sebagai filem auteur yang mempunyai kelasnya yang tersendiri.
\end{abstract}

Keywords: myth, Colonialism, Auteur, Malay film, Neo-Noir

\title{
INTRODUCTION
}

Dain Said has emerged as one of the most reputable directors in the Malaysian film industry. He has directed three films, the first being Dukun (Shaman, 2007), which failed to be screened due to its depiction of local controversial issues. Dukun was finally released for screening on 5th April 2018 and has since earned almost RM10 million in profit. However, his following film, the thriller Bunohan (2011), instantly placed him as one of the most important Malaysian film directors today. Bunohan had its world premiere at the 36th Toronto International Film Festival (TIFF) and received the NETPAC Award at the Taipei Golden Horse Film Festival. Bunohan was the winner of five major awards at the 2013 Malaysian Film Festival (Best Film, Best Director, Best Screenplay, Best Story and Best Actor).

Following the success of Bunohan was Dain's third film, Interchange (2016). Interchange's world premiere screening was at the iconic outdoor screen of the Locarno Film Festival and Asian premiere was at the Singapore 
International Film Festival on 23rd November 2016. It was also screened at several prestigious film festivals such as the Toronto International Film Festival, Vladisvostok International Film Festival and British Film Institute London Film Festival.

In both films, Dain plays with the theme of killing. This article, however, will further examine and analyze the elements of myth, capitalism and neocolonialism as the themes of the films.

\section{FILM AND MYTH}

Film is the supreme medium for mythmaking. Film as an art has blurred the line between reality and illusion. Maszalida (2006) has summed up the metamorphosis between illusion and reality in film. According to her, when images are projected onto the screen and viewed by the audience, it is nothing more than a shadow play. What is projected is not real but an imitation of the real that is recorded, fictionalized and animated for identification by the audience. Films then are not the representation of reality but a projection of reality. How we look at images, hear sounds and how images and sounds create meaning could be explained and explored semiotically (Benshoff, 2016). Semiotics analyzes the structural relations within a system that function to produce meaning. In film theory, semiotics explicitly uncovers the naturalization process of realism by opening up filmic text to show how meaning is produced (Hayward, 2000). Signification from film will then be read or interpreted according to a particular culture, ideology or national identity.

On the other hand, myth is a concept that primarily refers to a significant process through which any given society explains its history and culture. Myths are part of everyday life and may change across time. They then become part of the ideological process of naturalization (Hayward, 2000). Myth is a story based on a legend that has a symbolic meaning; for example, the Malay Sultanate traces its origins to Iskandar Zulkarnain (Alexander the Great). Legend is a folktale or traditional story with an unknown author that has been compiled and passed on across generations. The authority of the names and places in a legend could not be proven (Ahmat, 2016). In other words, myth is a traditional story about the past that has been infused with fantastic elements. Every society has its own myth such as folklores of the origin of one's race that include fantastic supernatural events. Besides explaining the origin of a race, myth is important and has its own role in the development of a political institution or country. Myth is aimed 
to psychologically exaggerate some fantasised heroes. The magnificent creation of heroes portrayed in myth is a profound example of divine and natural origin while also conveying the perceptions of power, dominance and superiority that have shaped the development of customs and cultures. The effect of myth on the individual and collective belief of human beings has influenced their thought and perception of realities (Leonard, S \& McClure, M, 2004).

\section{THE IMPORTANCE OF MYTH}

Myths and legends are important to us: they have value as literature, contain timeless and universal themes and provide insight into other times and places. Myths tell us what a culture considers to be ethical, significant and central to its ideologies while simultaneously allowing others to gain insight into the said culture. It is interesting how myths that captivated human beings in ancient times continue to do so in the minds of modern people. Some mythological works by Plato, Sophocles and Euripides still capture our imagination and thought, sprouting cultures and influencing humanity. An important reason why Greek mythology continues to be studied is because they have significantly contributed to classical and modern literature in the form of belief and symbols. Myth as fantasy transcends language. Although fantasy literature relies on language as its vehicle and also commonly features it as a thematic component, quality fantasy works relies on transcending language as myth (Lewis, 1982).

In terms of film as a cultural artefact, Barthes' assertion that film is a sign of system that functions mainly on the level of myth and thus loses all tangible references to the real world equally applies to mainstream film and its desire for the reality effect. Myth and fantasy in general narrate stories that would be impossible in the real world because they often involve mythical creatures or events that circumvent physical laws. The roots of fantasy fiction are in ancient myths, legends and folk tales. Interestingly, J. R. R. Tolkien characterized fantasy as a literature of hope. However, the emphasis on hope, happy endings and a rejection of cynicism has encouraged several scholars and critics to ignore fantasy and accuse it of escapism as it encourages the audience to abandon real-world problems. Ideologically associated as naïve and childish, fantasy films as a genre are neither horror nor science fiction. Horror is distinguished from fantasy as its objective is to scare the audience through specific themes and iconography such as dark and stormy nights, monster and vampires although modern horror may 
not feature any supernatural element. Science fiction refers to stories that extrapolate from rational and scientific principles with certain iconography such as spaceship, robots and advanced technology. It is noteworthy that certain films overlap these genres, combining horrific and deadly monsters in a futuristic outer-space setting such as Alien (1979), which is arguably both horror and science fiction (Fowkes, 2010).

\section{BUNOHAN - WHO IS THE REAL KILLER?}

Bunohan is a complex and tragic story of love, murder, passion and haunting memories between three estranged brothers and their ailing father. It has a simple storyline of a wayang kulit puppeteer (or dalang in shadow play) named Pok Eng (Wan Hanafi Su) and his conflicting relationship with his first two sons, Ilham (Faisal Hussein) and Adil (Zahiril Adzim), and third son, Bakar (Pekin Ibrahim), by his second wife. The plot of the story switches between the kickboxer Adil, who goes by the moniker Bunga Lalang, and Ilham, who returns to the village after years of living as a sailor and has now become a cold-blooded assassin. While the clean, smart-looking and educated Bakar returns from the city to care for their ailing father, greed has him associated with barbarous crimes, corruption, deceit and dupery. Ironically Bakar is a teacher by profession. He wants the ancestral land in order to sell it to developers from the city. In order to get this land, Bakar bribes others to do away with his two stepbrothers and he himself kills his father who is adamant about leaving the land to Adil.

Bunohan is a sombre film that moves quietly and has many layers of meaning. The word "bunohan" means murder in Malay, but Bunohan is in fact the name of their village (Kampung Bunohan). As a film Bunohan is noirish, dark and shadowy. Each character has their own struggle with reconciliation, memories and loss. Behind a dutiful son to his ailing father is a mask covering his banality - a mask of vicious greed and corruption. Bakar displays concern for his father when in reality he is simply after the ailing man's 30 acres of prime land to sell to a businessman from the city, only to be transformed later into a resort and property development. Kickboxing is a violent fighting sports that could incur fatal injury or death. As an assassin, Ilham kills his victims without mercy. However, the real killer in this film is the unscrupulous power of capitalism.

Dain begins his film with the ending. It begins with performers of main puteri, the traditional art performance that involves a shaman who performs spiritual healing sessions, and the film ends with the same scene of main 
puteri. Main puteri, like many other Malay traditional art performances such as mak yong and wayang kulit, is not only for entertainment but for a more somber purpose, which is spiritual healing. In healing ritual, the shaman performs wind blandishment or isih angin (the technical term for semangat or spirit) as a treatment for a patient, who will be cured through theatrical movements (Madiha \& Quayum, 2010). In Bunohan, capitalism takes the form of the nice-looking Bakar. Besides killing his father, Bakar symbolises modernism and commercialism as elements of capitalism that have destroyed old traditions, culture and eventually the spirit of the Malay psychic. The death of Pok Eng, the puppeteer and traditional art performer, is the result of a greedy capitalist. The actual death in Bunohan is the psychic and spirit of tradition and culture. The entire family of Pok Eng is destroyed and their ancestral land, which is highly symbolic and important in preserving the culture and tradition of a society, is ultimately lost to capitalism when a notice board informing of a new development is erected at the site.

The complexity and perplexity of Bunohan's plot is in the characters of Bakar and Adil, who are reflected on the television screen at the village coffee shop while the main puteri performers are talking about their characters on the screen. When Dain begins and ends the film with the same scene, we can assume that the entire story developed in the film could have been imaginary and told by the main puteri performers. The story could be just as any other traditional theatre story where the characters emerge as real. One of the most brilliant and important scenes in Blow-Up (Antonioni, 1961) is the murder scene being accidentally photographed by Thomas during a rendezvous in a park at Swinging London. The question then becomes whether the murder really happened. Thomas wonders into the park and snaps photographs of a couple but the woman runs after him. When Thomas blows up the photographs and analyzes the grainy and dotted images, which look more as an abstract painting, he realises that he may have photographed a murder. Later that night, Thomas visits the location of the murder and finds the corpse still there, half hidden among some bushes. However, at the end of the film, Thomas returns to the park where the murder happened and finds no corpse; it has simply disappeared with no evidence and no witness. As he wanders on his way home, he encounters students miming a tennis match. Thomas mimes throwing them the tennis ball and actually sees the ball. The film ends with the disappearance of the photographer, just as the corpse. The photograph is the symbol to be interpreted. The audience has to interpret the photographs and plausibility of the scene. For Antonioni, 
the murder scene is not important. The ending of the film questions realism and the narrative that separates reality and fiction (Goldman, 2008). While a writer may have to complete the narrative, the same is not required of a visual artist. The film may not depend on what is seen but what is thought to be seen. The same may apply with Bunohan.

\section{INTERCHANGE - RETURN TO THE ROOTS}

Interchange is a story about Adam (Iedil Putra) who works as a freelance forensic photographer for the Metropolis police, specifically for detective Man (Shaheisy Sam). Man knows of Adam's special gift that allows him to see certain visions and seeks Adam's help to solve a string of unusual ritualistic murders that have been taking place in the city. The strange common element about the murders is the way the corpses are left by the killer: hanging from the ceiling with alien-like fronts protruding from inside the corpses. Also found at every murder scene are pieces of broken glass plate negatives that were used in photography before the invention of celluloid film. The broken negatives are taken to expert photographer Uncle Heng (Che Kin-wah) to have them developed and Adam discovers that they are negatives taken by the Norwegian photographer and explorer, Carl Lumholtz, who trekked through Borneo's Central Kalimantan between 1913 to 1917. Lumholtz photographed the customs of the indigenous Tingang tribe, whose totem is the helmeted hornbill (a rare species of hornbill). From Lumholtz's book, Adam sees a resemblance between the murdered victims and members of the disappeared Tinggang tribe. One of the tribeswoman is the splitting image of Iva (Prisia Nasution), the neighbour that Adam has been spying on using his camera. The spying scene is a reference to the film Rear Window by Alfred Hitchcock. Then there appears a shady man, Belian (Nicholas Saputra), a hooded figure with a beaky nose and talons that resemble a bird, roaming the city's dark alleys but careful not to make contact with strangers. He speaks with an accent to Sani (Nadiya Nisa) who owns an antique shop. From there on, the plot thickens and the relationship between Belian, Iva, Sani and lastly Adam are carefully exposed. They all have roots in the Tingang tribe and are strangely on the journey of mortality. The Tingang tribe believes that the ritualistic mortality is a metamorphosis from human being to a hornbill. 


\section{INTERCHANGE AS A NEO-NOIR FILM}

As in his earlier film Bunohan, Dain Said again uses ancient cultures and myth to merge with modernity. Even though the plot and subplots may confuse the audience and could have been refined further, the visual effects of the film is its strongest feature. The structure of the plot, the stylistic visuals with sensual and saturated images of a city, the enigmatic women, the cocky detective and the lonely photographer make Interchange a neo-noir film.

The film term "noir" (meaning dark) was first applied to a group of American films made in the early 1940s by the French film critics in the magazine, Cinema du-Cahiers. According to Crowthers (1990), film noir as a genre can be distinguished by its dramatic camera works, visual images of rain-lashed streets, fogbound runways, sharply contrasted lighting and empty, the sun rarely shining and most of the scenes were shot in either real or simulated darkness. Film noir is very much concerned with certain sensibilities, emotions, attitudes and human failings, particularly pessimism, sexual obsession, deceit and fatalism. The main character is always a man who is usually isolated, either physically or mentally. The women in film noir is a femme-fatale or a powerful woman who uses her sexuality to attract men to their doom and is seen through misogynistic eyes. Film noir is a genre set within American life. Some fine examples of early film noir are Double Indemnity, Touch of Evil, Sunset Boulevard, Murder, My Sweet, Farewell My Lovely, Spellbound, The Big Sleep, The Blue Dahlia and The Maltese Falcon. However, an attempt to recreate the nostalgia or features associated with noir, its style, culture, psychology and vulnerable characters with emphasis on violence, anxiety, death, crime and compromised morality has resulted in a new noir or "neo-noir" (Neale, 2000). Neo-noir is now an accepted term for films that were produced from the mid-1960s onwards. Some examples of neo-noir films are Chinatown, The Postman Always Rings Twice, The Grifters and L.A. Confidentials. The local film Kala Malam Bulan Mengambang (2008), directed by Mamat Khalid, is also a neo-noir film.

\section{SUPERNATURAL MYTHS VS COLONIALISM AND CAPITALISM}

In Bunohan and Interchange, the director has delved into ethno-mysticism, which implies tradition and spiritualism. The usage of the traditional theatre of main puteri, wayang kulit and the healing ritual session in Bunohan is combined with the emergence of a lady (the character of Mek Ani, wife of 
Pok Heng) who can metamorphosise into a buaya putih (grandsire white crocodile) and possess magical powers. In two scenes, a white crocodile appears from a swamp to become a woman and heals the wound suffered by Adil and Ilham. In Interchange, Belian is transform into a helmeted hornbill through a ritualistic killing. The victims seem to willingly surrender to the killer as they are from the same tribe. Belian, in his transformation into a birdman, gains strange supernatural powers. Both animal transformations show the relationship between human beings and spiritual animals. These animistic characters are symbolic of ancient beliefs (Ghulam-Sarwar, 2015).

Symbolically, Dain Said uses traditional cultures and myth as two very important elements or foundations to defend a society from colonialism and globalization. In Bunohan, globalization and neo-colonialism come in the form of media (television) and capitalist project confrontations. Theodor Adorno and Horkheimer from the famous Frankfurt School of critical theory have criticized capitalists who control the mass media such as cinema and television as part of the capitalist base superstructure. This superstructure is a dangerous ideological instrument that only serves capitalist interests. The Frankfurt School has coined the term "culture industry" to refer to institutions that mass produce cultural artifacts such as film and popular music. The Frankfurt School have theorized how culture itself was produced in the twentieth century and, more importantly, what the ideological effects of such mass produced culture have on its consumers (Benshoff, 2016). For Adorno, culture industry is regarded as pervasively ideological, although he differentiates between film as an art form and film as an industry. However, he later wrote about the dictatorship of the culture industry and how the cinema, as the central sector of the culture industry, was emphatically linked with authority (Vighi, 2012).

\section{CONCLUSION}

Dain Said is an auteur filmmaker. He is consistent in his theme, style and strong visual effects. Both his films, Bunohan and Interchange, deal with the ideologies of capitalism and neo-colonialism. He shows in both films that the society of a country can resist neo-colonialism with a strong realization of their own traditions and mythology. Interestingly, Asiah (2006) has noted that a nation is the product of modernization and modernity and also of the secular modern intelligentsia that creates and disseminates the historical myths of nationhood. In both films, Dain argues how modernity brought by neo-colonialism and capitalism have slowly destroyed the traditions and 
culture of people. When tradition and culture are destroyed, the people and society will lose their identity. That is the ideological effect of the culture industry as disseminates by such mass produced culture.

Based on the discussion above, it is clear that Dain Said as a filmmaker has taken the theme of killing beyond audience's understanding. In both film, killing seems to be the main action but Dain also shows that the real killer is not the physical man hired to kill or the shady man who walks in the dark city alleys but the death or deconstruction of an ethnic or a race that happens when they lose their identity.

\section{REFERENCE}

Ahmat Adam. (2016). Antara sejarah dan mitos: Sejarah Melayu \& Hang Tuah dalam historiografi Malaysia. Petaling Jaya: SIRD.

Asiah Sarji. (2006). Malaysian national cinema: An identity crisis? Jurnal Skrin Malaysia 3.

Benshoff, H.M. (2016). Film and television analysis: An introduction to methods, theories, and approaches. London: Routledge.

Crowther, B. (1990). Film noir: Reflections in a dark mirror. London: Virgin Books Fowkes, Katherine A. (2010). The fantasy film. West Sussex: Wiley-Blackwell.

Goldman, P (2008). Blow-up, film theory, and the logic of realism in Anthropoetics XIV, no. 1, summer 2008. ucla.edu

Hayward, S. (2000). Cinema studies: The key concepts. London: Routledge.

Leonard, S. \& McClure, M. (2004). Myth \& knowing. An introduction to world mythology. Boston: McGraw-Hill.

Lewis, C.S. (1982). On stories and other essays on literature. Orlando, FL: Harcourt. Madiha Ramlan \& Quayum, M.A. (December 2010). Mapping the history of Malaysian theatre: An interview with Ghulam-Sarwar Yousof. Asiatic 4(2).

Maszalida Hamzah. (2006). The blurring dots between illusion in film: A metamorphosis. Jurnal Skrin Malaysia 3, 1 - 13.

Ghulam-Sarwar Yousof. (2015). Traditional Malay theatre: A comprehensive work by a Malaysian scholar. Kuala Lumpur: PTS Publications \& Distributors.

Neale, S. (2000). Genre and Hollywood. London: Routledge.

Vighi, F. (2012). Critical theory and film: Rethinking ideology through film noir. New York: Bloomsbury.

Received: 3 September 2018

Accepted: 3 October 2018 